\title{
BIOGRAFI DATU SANGGUL
}

\author{
Muhammad Risalan Uzhma \\ Email: 2010128110004@mhs.ulm.ac.id \\ Program Studi Pendidikan IPS Fakultas Keguruan dan Ilmu Pendidikan \\ Universitas Lambung Mangkurat \\ Banjarmasin
}

\begin{abstract}
Abstrak
Biografi adalah riwayat hidup seseorang yang ditulis oleh orang lain. Salah satu contoh dari biografi tokoh yang ada di Kalimantan Selatan adalah biografi Datu Sanggul. Datu Sanggul adalah salah seorang ahli sufi yang lahir pada abad ke 18, dan memiliki tekad yang kuat dalam menuntut ilmu, bahkan sampai ke Kalimantan Selatan dengan mempelajari ilmu kesempurnaan kepada Datu Suban. Artikel ini akan membahas tentang Datu Sanggul yang berasal dari Palembang dalam menuntut ilmu ke Kalimantan Selatan sampai beliau wafat dan dimakamkan di Tatakan. Penelitian ini memiliki tujuan untuk menceritakan dan menjelaskan tentang riwayat hidup Datu Sanggul. Penulisan artikel ini dengan menggunakn metode kualitatif dengan mendeskripsikan biografi dari Datu Sanggul. Teknik pengumpulan data yang digunakan adalah teknik wawancara dan studi literatur.
\end{abstract}

\section{PENDAHULUAN}

Biografi adalah riwayat hidup seseorang yang ditulis oleh orang lain. Biografi ini memiliki tujuan untuk menceritakan kembali masa hidupnya seseorang sampai dia wafat. Biografi berisi cerita tentang bagaimana hidup seseorang dari awal sampai kematian untuk memberitahu peristiwa pada saat itu (Handy \& Fatimah, 2019). Salah satu contoh dari biografi tokoh yang ada di Kalimantan Selatan adalah biografi Datu Sanggul.

Datu Sanggul adalah salah seorang ahli sufi yang bertempat di Tatakan, Kecamatan Tapin Selatan Kabupaten Tapin Provinsi Kalimantan Selatan. Datu Sanggul 
memiliki nama asli Muhammad Abdus Shamad yang berasal dari Sumatera Selatan lebih khususnya di Palembang yang lahir pada abad ke 18.

Datu Sanggul adalah orang yang suka menuntut ilmu, saat dia mengetahui dimana ada seorang guru atau ulama yang memiliki sebuah ilmu, Datu Sanggul tidak ragu-ragu untuk berguru kepada guru atau ulama tersebut, dengan tujuan untuk mempelajari ilmu tersebut. Salah satu guru dari Datu Sanggul adalah Datu Suban. Datu Sanggul rela pergi dari kampung halamannya di Palembang Sumatera Selatan untuk berguru kepada Datu Suban yang ada di Muning daerah Tatakan.

\section{METODE PENELITIAN}

Metode yang digunakan adalah metode kualitatif dengan teknik pengumpulan data dengan teknik wawancara ke responden di sekitar tempat penelitian dan studi literatur dengan menggunakan berbagai sumber yang didapatkan dari buku, dan jurnal yang relevan untuk menceritakan dan menjelaskan biografi Datu Sanggul.

\section{KEDATANGAN DATU SANGGUL DI MUNING}

Datu Sanggul adalah orang yang tekun dalam menuntut ilmu, sehingga di rela untuk datang ke Muning untuk menuntut ilmu kepada Datu Suban. Datu Sanggul datang ke Muning karena mendapat mimpi pada saat setelah shalat dzuhur, pada saat itu Abdush Samad ditemui oleh seorang orang tua yang mengatakan bahwa jika kamu ingin mempelajari tentang ilmu kesempurnaanatau ilmu sejati maka hendaknya kamu pergi desa Muning (sekarang Tatakan) kepada Datu Suban untuk mempelajari ilmu tersebut. Setelah mendengar orang tua tersebut, Abdush Samad langsung terbangun dari tidurnya dan memohon kepada ibunya dengan kesungguhan meminta persetujuan dari ibunya dengan mencium kedua tangan dan kaki ibunya. Akhirnya Abdush Samad mendapat persetujuan dari ibunya untuk menuntut ilmu kepada Datu Suban di desa Muning kepada Datu Suban. 
Abdush Samad kemudian berangkat menuju desa Muning dengan menggunakan perahu layar dengan hanya mengandalkan tenaga angin, Abdush Samad akhirnya tibadi Kalimantan Selatan setelah satu bulan dengan kapal layar yang Abdush Samad gunakan. Setelah sampai di Kalimantan, Abdush Samad melakukan perjalanan darat dan akhirnya bertemu dengan seorang lelaki. Lelaki tersebut bernama Tamingkarsa, kemudian Abdush Samad bertanya kepada Tamingkarsa sebagaimana yang tercantum dalam buku Manakib Datu Sanggul Karya Tim Sahabat (2013), dikatakan bahwa Abdush Samad meminta bantuan kepada Tamingkarsa untuk dipertemukan dengan Datu Suban "Hamba ingin bertemu dengan Datu Suban untuk berguru kepada beliau".

Tamingkarsa kemudian membawa Abdush Samad kepada Datu Suban yang berada di pantai Munggutayuh, desa Muning. Sesampainya mereka disana, Tamingkarsa mengucapkan salam kepada Datu Suban, dan diberikan balasan salam dari Datu Suban. Mereka dipersilahkan untuk masuk oleh Datu Suban, kemudian Tamingkarsa menyampaikan tujuan dari Abdush Samad datang kepada Datu Suban,pada saat itu juga Abdus Shamad duduk bersimpuh dan berlutut serta mencium kedua tangan dan kaki Datu Suban untuk menjadi murid dari Datu Suban. Abdush Samad menyampaikan apa yang ada dimimpinya dan dia memiliki hajat untuk melaksanakan apa yang ada dimimpinya tersebut. Akhirnya Datu Suban menerima Abdush Samad untuk menjadi muridnya, dan mengangkat Abdush Samad menjadi anak dunia akhirat.

\section{MENUNTUT ILMU DENGAN DATU SUBAN}

Abdush Samad yang telah diangakat menjadi murid dan anak dunia akhirat, Abdush Samad mulai melakukan proses pembelajaran kepada Datu Suban, dan beliau hanya mempelajari tentang ilmu agama yang meliputi ilmu tarekat, ilmu hakikat (tasawuf), ilmu ma'rifat dan ilmu muhasyadat (Sahabat, 2013).

Murid-murid dari Datu Suban berjumlah 13 orang, dan Abdus Samad adalah murid terakhir dari Datu Suban. Walaupun Abdus Samad murid terakhir dari Datu Suban, akan tetapi Abdush Samad adalah murid yang paling disayangi, karena Abdush Samad adalah orang yang rajin dan giat dalam melakukan perintah tuhan dan gurunya 
yang tidak dapat dilakukan oleh murid Datu Suban yang lain. Adapun kitab yang dipelajari oleh Murid dari Datu Suban adalah Kitab Barencong. Kitab Barencong ini adalah salah satu kitab agama yang dibawa oleh Datu Nuraya dan diberikan kepada Datu Suban untuk diajarkan kepada murid-muridnya (Hidayati, 2017).

Kitab Barencong tersebut kemudian diwariskan kepada Abdush Samad, karena menurut Datu Suban hanya Abdush Samad saja yang dapat mempelihara kitab tersebut dan murid-murid Datu Suban sebelumnya juga mendapatkan ilmu pengetahuan yang khsusus yang tidak dimiliki oleh murid yang lainnya. Abdush Samad sedikit keheranan, mengapa tidak Tamingkarsa saja yang mendapatkan kitab itu dan juga takut jika nantinnya ada ketersinggungan dari para murid yang lainnya. Kemudian, Datu Suban memberikan jawaban bahwa murid-murid Datu Suban yang lainnya telah setuju dengan keputusan yang telah diberikan oleh Datu Suban mengenai pemberian kitab Barencong kepada Abdush Samad, akhirnya dia pun menerima permintaan dari gurunya tersebut.

Pada saat berguru dengan Datu Suban, Abdush Samad melakukan pertapaan selama 10 bulan atau 40 kali Jumat. Dalam proses pertapaan, Abdush Samad mendapatkan kemudahan dan pertolongan, sehingga tidak menemui tantangan dan rintangan dalam proses bertapa. Hal itu karena Allah SWT., kerelaan dan doa orang tua serta gurunya untuk kelancaran menuntut ilmu.

\section{PEMBERIAN GELAR DATU SANGGUL}

Gelar Datu Sanggul yang didapatkan oleh Abdush Samad diberi gelar Datu Sanggul karena beliau melakukan khalwat khsusus yang diperintahkan oleh Datu Suban kepada murid-muridnya dengan berbagai macam zikir yang dilakukan. Khalwat khusus ini dilaksankan dan diselesaikan sampai memperoleh ilmu ladunni. Ilmu ladunni ini adalah ilmu yang diizinkan dan diberikan Allah SWT. kepada hamba-Nya yang bertakwa, takwa disini dapat diartikan sebagai melaksanakan perintahnya dan menjauhi larangannya. Pada saat itu, khalwat khusus di sama artikan dengan menyanggul atau menunggu didapatkannya ilmu tersebut (ilmu ladunni) dari Allah SWT. Abdsuh Samad adalah orang yang paling tekun, takwa, dan tidak sombong, sehingga Abdush Samad 
mendapatkan ilmu tersebut, karena ketekunan dan kesabarannya dalam menyanggul ilmu ladunni. Maka dari itu Abdush Samad diberi gelar Datu Sanggul.

\section{PERSAHABATAN DATU SANGGUL DENGAN DATU KALAMPAYAN}

Datu Sanggul dengan Datu Kalampayan (Syekh Muhammad Arsyad Al-Banjari) seperti halnya saudara, yang saling membantu satu sama lain. Datu Sanggul bertemu dengan Syekh Arsyad Al-Banjari saat shalat Jumat di Mekah. Pada saat itu Syekh Arsyad Al-Banjari sedang menuntut ilmu di tempat tersebut. Setelah mereka bertemu, Datu Kalampayan mengajak Datu Sanggul untuk pergi ke rumah Datu Kalampayan. Sesampainya di rumah, Syekh Arsyad mengatakan "Anda adalah saudaraku dunia akhirat" sambil mencium kedua tangan dan kaki Datu Sanggul. Kemudian mereka berdua, saling berintaraksi dan Datu Sanggul menceritakan tentang gurunya yaitu Datu Suban. Setelah itu, Syekh Arsyad tertarik dengan kitab yang dipelajari oleh Datu Sanggul kepada Datu Suban. Datu Sanggul menerima permintaan tersebut, akan tetapi kitab tersebut dibagi menjadi dua bagian, yang satu di bagian Datu Sanggul dan yang satunya lagi di Syekh Arsyad Al-Banjari.

Datu Sanggul berpesan kepada Syekh Arsyad, jika Syekh Arsyad ingin mempelajari bagian kitab ini yang lainnya maka Syekh Arsyad harus pulang ke Borneo (Kalimantan), dan juga Datu Sanggul minta bawakan Kain Putih sebanyak lima lembar, dan jangan lupa membawakan yang demikian. Setelah hal tersebut, Datu Sanggul minta izin untuk pulang ke Muning kepada Syekh Arsyad Al-Banjari. Sebelum Datu Sanggul pulang, Syekh Arsyad meminta satu permintaan kepada Datu Sanggul, yaitu untuk dibawakan buah durian yang ada di halaman istana. Akan tetapi, Datu Sanggul ada perasaan ragu untuk mengambil durian tersebut karena hanya ada dua biji dan dijaga ketat oleh para penjaga istana, kemudian Syekh Arsyad meyakinkan Datu Sanggul, dan akhirnya Datu Sanggul mengiyakannya.

Hari jumat berikutnya, Datu Sanggul berangkat kembali ke Mekkah dan sebelum itu, beliau datang ke halaman istana untuk memetik buah durian pesanan dari Syekh Arsyad, seteleh memetik Datu Sanggul langsung membawa ke Mekkah dan memberikannya kepada Syekh Arsyad. Kemudian Syekh Arsyad mengajak Datu 
Sanggul kerumahnya kembali, dan pada saat itu Datu Sanggul mengatakan bahwa ini adalah pertemuan terakhir antara kita ditempat ini, jika engkau telah menyelesaikan mempelajari kitab ini dan ingin mempelajari bagian kitab yang lainnya maka datanglah kamu ke Muning dengan persayaratan yang sebelumnya telah saya sampaikan. (Sahabat, 2013). Setelah selesai mempelajari dan menyelesaikan kitab tersebut, akhirnya Syekh Arsyad Al-Banjari kembali ke Martapura dan hendak menemui Datu Sanggul untuk mempelajari bagian lain dari Kitab Barencong.

\section{WAFATNYA DATU SANGGUL}

Setelah Syekh Arsyad kembali ke Martapura pada tahun 1772, beliau pun disambut oleh para raja dan rakyat raja, kemudian Syekh Arsyad meminta izin kepada raja untuk ke kampung Muning untuk menemui Datu Sanggul. Permintaan tersebut disetujui oleh raja, dan raja memerintahkan lima pengawalnya untuk menemani Syekh Arsyad ke kampung Muning untuk menemui Datu Sanggul. Di lain tempat, Datu Sanggul melaksanakan shalat subuh berjamaah dengan murid-muridnya, namun ada yang berbeda pada saat itu. Pada saat itu, Datu Sanggul memerintahkan murid-muridnya untuk bertahan karena ada yang ingin disampaikan. Datu Sanggul mengundang murid dan murid-murid untuk menyampaikan undangan untuk bergotong royong dan mengerjakan beberapa pekerjaan pada kurang lebih pukul sembilan. Setelah mendengar perkataan dari Datu Sanggul, murid-murid Datu Sanggul kemudian meninggalkan tempat tersebut, dan menyampaikan pesan dari Datu Sanggul untuk masyarakat sekitar.

Pada waktu yang ditentukan tiba, murid-murid dan masyarakat telah banyak yang berdatangan, Datu Sanggul kemudian memulai kegiatan tersebut dengan memberikan salam kepada semua dan membagi mereka dalam beberapa bagian yaitu mendirikan sarubung, mencari kayu bakar, memetik buah kelapa, menebang pohon kelapa, dan membuat tenda untuk memasak nasi (Sahabat, 2013). Mereka melakukan pekerjaan tersebut dengan saling membantu dengan dipimpin oleh Datu Sanggul, akhirnya pekerjaan mereka dapat diselesaikan dengan baik dan lancar. Kemudian mereka menunggu waktu zuhur, mereka makan dan minum dengan seadanya. Setelah waktu zuhur tiba, mereka melaksanakan salat zuhur berjamaah dengan dipimpin oleh Datu 
Sanggul. Kemudian, Datu Sanggul memberikan wasiat dan pesan untuk mereka. Setelah pesan disampaikan oleh Datu Sanggul, mereka semua saling berpelukan dan bersalaman dengan saling memaafkan satu sama lain.

Keesokan harinya pada hari jumat, setelah selesai melaksanakan shalat subuh berjamaah, Datu Sanggul memanggil isterinya yang bernama Siti Sarah untuk menyampaikan bahwa Datu Sanggul akan tidur dan jangan diganggu, kecuali ada kepentingan yang sangat penting. Pada saat matahari yang sudah berada tepat diatas kepala, isteri Datu Sanggul merasa heran mengapa suaminya ini belum bangun untuk melaksanakan shalat jumat. Mulai ada dipikiran isteri Datu Sanggul untuk membangunkan Datu Sanggul, akan tetapi isterinya tersebut teringat dengan wasiat yang diberikan. Kemudian, isteri Datu Sanggul berpikir sebentar untuk mengambil keputusan yang akan diambil.

Isteri Datu Sanggul mengambil keputusan untuk memberanikan untuk memanggil suaminya, hingga tiga kali dan tidak ada jawaban yang diberikan. Melihat hal tersebut, isteri Datu Sanggul kembali memberanikan diri untuk masuk ke kamar tidur dan membuka kelambu. Betapa terkejutnya isteri Datu Sanggul melihat suami yang begitu dicintainya sudah tidak ada lagi dan hanya menemukan air yang sangat bening dan putih. Setelah menyaksikan hal tersebut, Siti Sarah kembali menutup kelambu tersebut dengan perasaan kebingungan yang masih ada.

Tidak selang beberapa lama datang rombongan Syekh Arsyad, kemudian Syekh Arsyad mengucapkan salam dan bertanya "Apakah ini kediaman dari wali Abdus Samad?", kemudian dijawab oleh Siti Sarah, "Ya, ini kediaman beliau“. Syekh Arsyad kemudian meminta untuk dipanggilkan Datu Sanggul karena ada hal yang harus dilakukan. Kemudian, isteri Datu Sanggul bergegas menuju kamar dan membuka kelambu tersebut lagi, dan dia melihat Datu Sanggul sudah tidak dapat bernafas lagi, isteri Datu Sanggul kemudian mendatangi Syekh Arsyad kembali dengan mengatakan “Inna Lillaahi wa Innaa Ilaihi raaji’un, Datu Sanggul sudah meninggal dunia“. Pantas saja kata Syekh Arsyad, Datu Sanggul ingin dibawakan lima lembar kain putih.

Pada saat itu diberitahukan kepada murid-murid dan masyarakat sekitar, maka datanglah mereka ke rumah Datu Sanggul dan melaksanakan pengurusan jenazah 
hingga selesai. Kemudian Syekh Arsyad bertanya kepada Siti Sarah, "Apakah Datu Sanggul pernah bercerita bahwa mereka berdua bersaudara dan bertemu di Mekkah“, dari Syekh Arsyad. Kemudin diberikan jawaban "ya memang ada". Kemudian Syekh Arsyad menceritakan kembali maksud beliau datang yaitu untuk meminjam bagian lain dari kitab Barencong yang ada pada Datu Sanggul. Kemudian, isteri Datu Sanggul berdiskusi dengan murid-murid Datu Sanggul, dan akhirnya diberikan lah bagian lain dari kitab tersebut kepada Syekh Arsyad. Kemudian Syekh Arsyad, pamit pulang kepada semua untuk kembali ke Martapura dengan membawa kitab Barencong.

\section{MAKAM DATU SANGGUL}

Makam Datu Sanggul terletak di Muning (Tatakan). Tatakan sendiri merupakan bagian dari Kecamatan Tapin Selatan Kabupaten Tapin. Makam Datu Sanggul biasanya banyak diziarahi oleh orang-orang dari berbagai tempat. Di tempat tersebut biasanya orang-orang melakukan pembacaan yasin, dan doa baik dilakukan secara mandiri ataupun berjamaah ( Wajidi \& Anwar, 2018).

Desa Tatakan memiliki jalan darat yang baik sehingga mempermudah para orangorang untuk ziarah ke makam Datu Sanggul. Masyarakat didaerah Tatakan juga terkenal ramah, dan menerima orang dari tempat lain. Di daerah tersebut juga banyak ditemui toko-toko yang menjual berbagai macam kerajinan. Selain itu juga terdapat perlengkapan untuk shalat seperti tasbih, minyak harum, peci, dan sebagainya.

\section{SIMPULAN}

Biografi adalah riwayat hidup seseorang yang ditulis oleh orang lain. Biografi ini memiliki tujuan untuk menceritakan kembali masa hidupnya seseorang sampai dia wafat. Salah satu contoh dari biografi tokoh yang ada di Kalimantan Selatan adalah biografi Datu Sanggul. Datu Sanggul adalah salah seorang ahli sufi yang lahir pada abad ke 18. Datu Sanggul adalah orang yang suka menuntut ilmu, bahkan dia sampai menuntut ilmu sampai ke Kalimantan yaitu kepada Datu Suban yang ada di Muning daerah Tatakan. Tujuan penelitian ini untuk menceritakan dan menjelaskan mengenai 
riwayat hidup Datu Sanggul. Metode yang digunakan adalah metode kualitatif dengan teknik pengumpulan data dengan wawancara dan studi literatur.

Abdush Samad yang telah diangakat menjadi murid dan anak dunia akhirat, Abdush Samad mulai melakukan proses pembelajaran kepada Datu Suban, dan beliau hanya mempelajari tentang ilmu agama. Murid-murid dari Datu Suban berjumlah 13 orang, dan Abdus Samad adalah murid terakhir dari Datu Suban. Adapun kitab yang dipelajari oleh Murid dari Datu Suban adalah Kitab Barencong.

Gelar Datu Sanggul yang didapatkan oleh Abdush Samad ada beberapa pendapat mengenai hal tersebut antara lain melakukan khalwat khsusus, dan melakukan pekerjaan duduk diatas pohon, dengan senjata sumpit serta kepala dengan diikat rotan, menyanggul (menunggu untuk berburu) rusa atau menjangan.

Datu Sanggul bertemu dengan Syekh Arsyad Al-Banjari saat shalat Jumat di Mekah. Pada saat itu Syekh Arsyad Al-Banjari sedang menuntut ilmu di tempat tersebut. Datu Sanggul menceritakan tentang gurunya yaitu Datu Suban. Setelah Syekh Arsyad kembali ke Martapura, beliau pun disambut oleh para raja dan rakyat raja, kemudian Syekh Arsyad meminta izin kepada raja untuk ke kampung Muning untuk menemui Datu Sanggul. Di lain tempat dengan waktu yang berbeda pula, Datu Sanggul melaksanakan shalat subuh berjamaah dengan murid-muridnya, namun ada yang berbeda pada saat itu. Pada saat itu, Datu Sanggul memerintahkan murid-muridnya untuk bertahan karena ada yang ingin disampaikan.

Pada minggu berikutnya hari jumat, setelah selesai melaksanakan shalat subuh berjamaah, Datu Sanggul memanggil isterinya yang bernama Siti Sarah untuk menyampaikan bahwa Datu Sanggul akan tidur dan jangan diganggu, kecuali ada kepentingan yang sangat penting. Kemudian datang rombongan Syekh Arsyad untuk meminjam bagian kitab Barencong yang lain kepada Datu Sanggul. Akan tetapi, Datu Sanggulnya telah tiada dan akhirnya Datu Sanggul diurus jenazahnya dan dimakamkan di Muning (Tatakan), Kecamatan Tapin Selatan, Kabupaten Tapin. 


\section{REFERENSI}

Abbas, E. W., Mutiani, M., \& Nugraha, D. S. (2018). SOCIAL VALUES IN ZAINAL ILMI BIOGRAPHY AS LEARNING SOURCE OF SOCIAL STUDIES. In The 3rd ISSSHE International Seminar Sosial Studies \& History Education" Promoting The 21st Century Skills in Social Studies Learning". UNIVERSITAS LAMBUNG MANGKURAT.

Anwar, M. A. (2018). Potensi Dan Analisis Pengembangan Wisata Religi Kabupaten Tapin. Jurnal Kebijakan Pembangunan, 13(2), 199-121.

Handy, M. R. N., \& Fatimah, S. N. (2019). Biography of Syekh Muhammad Nafis AlBanjari: An Investigation of Value in the Spread of Islam as a Learning Source on Social Studies. The Kalimantan Social Studies Journal, 1(1), 40-50.

Hestiyana. (2020). Nilai-Nilai Pendidikan Karakter Dalam Riwayat Datu-Datu Banjar. Jurnal Lingko: Jurnal Kebahasaan dan Kesastraan.

Hidayati, D. (2017). Karakteristik Tokoh Dan Nilai Moral Dari Cerita Rakyat "Datu Ayuh Wan Bambang Siwara. LENTERA: Jurnal Ilmiah Kependidikan, 12(1), 110.

Hidayatullah, D. (2020). Legenda Syekh Muhammad Arsyad Al-Banjari Dan Pengaruhnya Pada Masyarakat Banjar. Balai Bahasa Provinsi Kalimantan Selatan.

Jumadi, J., \& Effendi, R. (2016). Tema dan Amanat Legenda Banjar. Eprints Universitas Lambung Mangkurat.

Kolis, N. (2019). Ajaran Tauhid Wujudiyah Di Kalimantan Selatan. Repository IAIN Ponorogo.

Subiyakto, B. (2015). Syekh Muhammad Arsyad Al-Banjari: Upaya dan Ajaran NilaiNilai Karakter dalam Pendidikan Ilmu Pengetahuan Sosial (Doctoral dissertation, Universitas Pendidikan Indonesia).

Tim Sahabat. (2013). Manakib Datu Sanggul. SAHABAT Mitra Pengetahuan. 